\title{
Anti-inflammatory effects of two lupane-type triterpenes from leaves of Acanthopanax gracilistylus on LPS-induced RAW264.7 macrophages
}

\author{
Jiao LUO ${ }^{1}$, Xiao-jun LI' ${ }^{1,2}$, Geon-ho LEE ${ }^{3}$, Jian-jun HUANG ${ }^{4}$, Wan-kyunn WHANG ${ }^{5}$, Xiao-dan ZHANG ${ }^{6}$, \\ Chang-soo $\mathrm{YOOK}^{7}$, Xiang-qian $\mathrm{LIU}^{1 \star}$ (D)
}

\begin{abstract}
Acanthopanax gracilistylus W.W.Smith (AGS) is an traditional Chinese medicine and its leaves that have rich biological activities has been long used as a fresh vegetable in Chinese folk. There are two lupane-type triterpenoids, 3a,11a-dihydroxy-23-oxolup-20(29)-en-28-oic acid (1) and 3a,11a,23-trihydroxy-lup-20(29)-en-28-oic acid (2), were isolated as the active constituents from leaves of AGS. However, the anti-inflammatory effects and potential mechanisms of $\mathbf{1}$ and $\mathbf{2}$ on LPS-induced RAW264.7 Macrophages have not been evaluated. In this study, the results shown that compounds $\mathbf{1}$ and $\mathbf{2}$ reduced the levels of early proinflammatory cytokines TNF- $\alpha$, IL- $1 \beta$, the secretion of late pro-inflammatory cytokine HMGB1, as well as the activation of

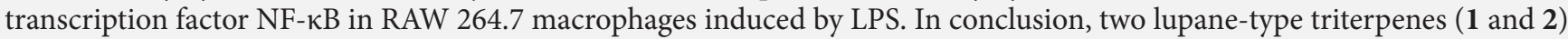
have anti-inflammatory activities in LPS-induced RAW264.7 cells through inhibiting expression of proinflammatory cytokines and NF- $\mathrm{KB}$ activation and could be potentially used in treatment of inflammatory-related diseases in the future.
\end{abstract}

Keywords: Acanthopanax gracilistylus W.W. Smith; lupane-type triterpenes; RAW 264.7 macrophages; proinflammatory cytokines; HMGB1; NF-кB.

Practical Application: 1. Two lupane-type triterpenes inhibited the LPS-induced production of TNF- $\alpha$, IL-1 $\beta$ and HMGB1 in the RAW264.7 cells. 2. It also suppressed NF- $\mathrm{kB}$ activation in the RAW264.7 cells. 3. Two lupane-type triterpenes isolated from the leaves of Acanthopanax gracilistylus may be able to inhibit the inflammatory diseases. 4 . This research provides a reliable theoretical and practical basis for application of the leaves of AGS as function food in the future.

\section{Introduction}

Macrophages are immune cells that can response to stimuli and secrete inflammatory mediators, as well as proinflammatory cytokines (Han et al., 2021). LPS, is a main component of the outer membrane of gram-negative bacteria, which has become the common revulsive to induce inflammation (Xiao et al., 2021). Therefore, LPS-stimulated macrophage is usually used to evaluate anti-inflammatory activities.

Inflammation is a biological response for protecting against and repairing damage from infections, injuries, chemical stimuli, and toxins (Hwangbo et al., 2021). However, recent studies have shown that acute and uncontrolled chronic inflammation is associated with multiple diseases, including rheumatoid arthritis, metabolic syndrome, inflammatory bowel disease, diabetes, and various types of cancer (Ahn et al., 2018; Xu et al., 2021a, b). Growing prevalence of these inflammatory-related diseases means they are now among the leading causes of morbidity worldwide (Hsieh et al., 2021; Wei et al., 2021). Therefore, finding effective and low-toxicity anti-inflammatory drugs to control inflammation is critical for the prevention or treatment

of these diseases (Tang et al., 2021). Inflammation results in the production of proinflammatory cytokines and other inflammatory mediators such as tumor necrosis factor (TNF)- $\alpha$, and IL- $1 \beta$, and high mobility group box 1 (HMGB1) (Insuan et al., 2021). HMGB1 plays a critical role in the pathophysiology of inflammatory diseases like sepsis (Yang et al., 2021; Hur et al., 2021). It is a late inflammation factor that may enlarge inflammatory response by causing elevated levels of other cytokines through stimulating macrophages to synthesize pro-inflammatory cytokines, which induce and promote each other (Yang et al., 2021). Moreover, recently the inhibition of HMGB1 is considered to be a promising therapeutic target for attenuating inflammatory respond (Zhou et al., 2018; Ni et al., 2020; Wang et al., 2020; Hur et al., 2021). Nuclear transcription factor $-\kappa B(N F-\kappa B)$ is a key transcription factor in inflammatory response (Luo et al., 2020). Activation of NF- $\kappa B$ plays a central role in inflammation through its ability to induce production and release of multiple pro-inflammatory cytokines and chemokines (Lin et al., 2021). These factors mediate and amplify the inflammatory response 
and are involved in the pathogenesis of many related disorders (Cao et al., 2021; Xiao et al., 2021).

Acanthopanax gracilistylus W.W.Smith is deciduous shrub of the Araliaceae family which is widely distributed in China (Chinese Pharmacopoeia Commission, 2015). Its dried roots and stem barks, named wujiapi, are listed officially in the Chinese Pharmacopoeia as Acanthopanacis Cortex, and used commonly to treat arthritis, rheumatism, paralysis, sinew, bone pains, lameness, and liver disease for many centuries in China (Shan et al., 1999). Its leaves have been used usually as a vegetable (State Administration of Traditional Chinese Medicine, 1999) in China and the previous pharmacological study on the leaves of AGS reported hepatoprotective effect (Zhang et al., 2011), antidiabetic effects (Lu et al., 2018) and anti-inflammation (Liu et al., 2017). In our previous studies. We researched its phytochemical constituents and obtained some lupane-triterpenoids (Liu et al., 2002, 2004, 2017; Yook et al., 2002; Zou et al., 2011, 2017). However, the anti-inflammatory activity and the mechanism of action of the biologically active components $\mathbf{1}$ and $\mathbf{2}$ of the leaves of AGS were seldom studied until now. Here, we used LPS-induced RAW264.7 murine macrophages cell line as an appropriate biological model to investigate the inhibitory effects of two lupane-type triterpenes ( 1 and $\mathbf{2}$ ) on the production of inflammatory mediators TNF- $\alpha$, IL-1 $\beta$, and HMGB1. To elucidate their potential mechanisms, the expression of TNF- $\alpha$, IL-1 $\beta$, HMGB1, and the translocation

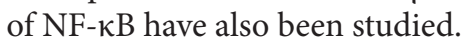

\section{Materials and methods}

\subsection{Plant material}

The leaves of AGS were collected in Changsha, Hunan province of China, in September 2016 and were botanically identified by Prof. Chang-Soo Yook, Kyung Hee University, South Korea.

\subsection{Chemicals and reagents}

RAW264.7 cell line was purchased from Shanghai Institute of Biochemistry and Cell Biology, Chinese Academy of Sciences (Shanghai, China). Lipopolysaccharide (LPS) and dimethyl sulfoxide (DMSO) were purchased from Sigma Chemicals (St. Louis, MO, USA). EZ4U cell proliferation and cytotoxicity assay kit was obtained from Biomedica (Vienna, Austria). AntiHMGB1 antibody was ordered from Abcam (Cambridge, UK), secondary antibody conjugated with horseradish peroxidaseconjugated goat anti-rabbit IgG was purchased from Beyotime Institute of Biotechnology (Jiangsu, China). Commercially available ELISA kits TNF- $\alpha$ and IL- $1 \beta$ were obtained from Invitrogen Corporation (Camarillo, CA, USA). RPMI 1640 medium and fetal bovine serum (FBS) were purchased from Gibco-BRL (Grand Island, NY, USA). The other materials under study were endotoxin free. These chemicals and reagents were based on our previous report (Liu et al., 2017).

\subsection{Extraction and isolation}

The isolation of lupane-type triterpenes ( 1 and $\mathbf{2}$ ) was described previously (Zou et al., 2011). Briefly, the dried leaves of
AGS (1000 g) were extracted for three times with hot methanol. The combined methanol extract was evaporated under reduced pressure to obtain a residue $(140 \mathrm{~g})$, which was dissolved in water and partitioned with petroleum ether, ethyl acetate, and n-butyl alcohol successively. A part of the residue of the ethyl acetate soluble fraction $(60 \mathrm{~g})$ was chromatographed on silica gel $(2.5 \mathrm{~kg})$, eluted with chloroform, with the polarity gradually increased with methanol (25:1, 20:1, 15:1, 10:1, $5 \mathrm{~L}$ for each gradient) to give four fractions (Fr.1-Fr.4). Fr.2 was chromatographed on silica gel and ODS column again to give compounds $\mathbf{1}$ and $\mathbf{2}$. The chemical structures of $\mathbf{1}$ and $\mathbf{2}$ were identified by analyzing the signals of spectral data $\left({ }^{1} \mathrm{H}\right.$ - and ${ }^{13} \mathrm{C}-\mathrm{NMR}, \mathrm{HMQC}, \mathrm{HMBC}$, COSY, ROESY, and MS) and were shown in Figure 1. The purity of compounds 1 and 2 were checked by HPLC analysis (> 98\% pure).

\subsection{Cell culture and stimulation}

Macrophages were cultured in Dulbecco Modified Eagle's medium (DMEM) supplemented with 10\% FBS, 100 units/mL penicillin and 100 units $/ \mathrm{mL}$ streptomycin in tissue culture dishes at $37^{\circ} \mathrm{C}$, in a humidified atmosphere of $5 \% \mathrm{CO}_{2}$ in air. For most experiments, cells were plated at a density of $1 \times 10^{6}$ cells/well on 12-well plates in $200 \mu \mathrm{l}$ DMEM. Adherent RAW264.7 cells in 12 -well culture plates were gently washed, and cultured in serumreduced OPTI-MEM I medium $8 \mathrm{~h}$ before treating with vehicle or various concentrations of IA (5-100 $\mu \mathrm{M}$, dissolved with $0.1 \%$ DMSO). One hour after treatment with various concentrations of compound or vehicle alone, LPS was added to a final concentration of $100 \mathrm{ng} / \mathrm{mL}$ at varying time intervals at $37^{\circ} \mathrm{C}$ until further analysis.

\subsection{Cytotoxicity assay}

The cytotoxicity of compounds $\mathbf{1}$ and $\mathbf{2}$ was assessed in RAW264.7 cells by an MTT-based test (EZ4U, Biomedica,

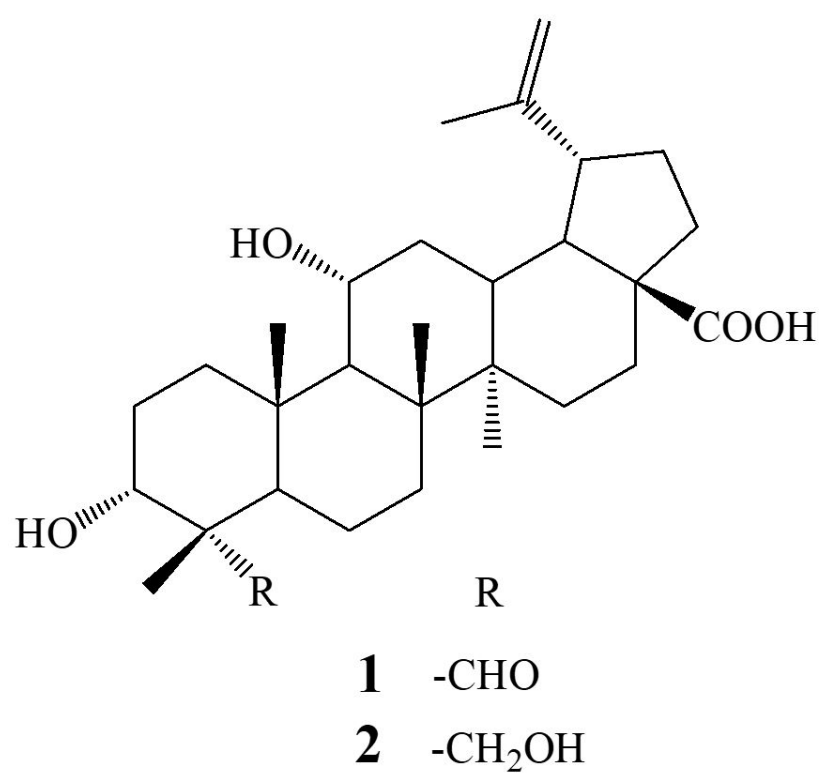

Figure 1. Chemical structures of lupane-type triterpenes (1 and 2). $3 a, 11 \alpha$-dihydroxy-23-oxo-lup-20(29)-en-28-oic acid (1), 3a,11a,23trihydroxy-lup-20(29)-en-28-oic acid (2). 
Vienna, Austria) following the manufacturer's instructions. $1 \times 10^{3}$ cells/well were seeded in triplicate in 96-well micro plates and cultured with various concentrations of compounds 1 and $2(5,25,50,75$, and $100 \mu \mathrm{M})$ for $48 \mathrm{~h}$ at $37^{\circ} \mathrm{C}$ with $5 \%$ $\mathrm{CO}_{2}$. Then $20 \mu \mathrm{L} \mathrm{EZ4U}$ (MTT-based dye) reagent was added to each well and incubated for $4 \mathrm{~h}$ at $37^{\circ} \mathrm{C}$. The absorbance was measured using a microplate reader (Perkin Elmer Cetus, Foster City, CA, USA) at $450 \mathrm{~nm}$ using an empty well with culture medium as reference. Values obtained from control wells containing cells and media alone were set to $100 \%$ proliferation. The relative cell viability (\%) related to control wells was calculated by $[\mathrm{A}]_{\text {test }} /[\mathrm{A}]_{\text {control }} \times 100$.

\subsection{Detection of TNF- $\alpha$ and IL-1 $\beta$ production}

Macrophages were pretreated with various concentrations (10, $20,30,40$, and $50 \mu \mathrm{M}$ ) of compounds $\mathbf{1}$ and $\mathbf{2}$ or Dexamethasone (positive control, $10 \mu \mathrm{M}$ ) for $1 \mathrm{~h}$ then exposed to LPS (100 ng/ $\mathrm{mL}$ ) for $6 \mathrm{~h}$. Culture media was collected and assayed using commercially available sandwich ELISA kits according to the manufacturer's instructions (Invitrogen Corporation, Camarillo, CA, USA). Briefly, $50 \mu \mathrm{L}$ of the incubation buffer, $50 \mu \mathrm{L}$ standard diluent buffer, $50 \mu \mathrm{L}$ standards, controls, or samples were added in triplicate to anti-TNF- $\alpha$ or anti-IL- $1 \beta$ coated ELISA microplates, and $50 \mu \mathrm{L}$ biotin conjugate solution to the appropriate anti-mouse monoclonal antibody coated microtiter wells except the chromogen blank successively. After incubation, the supernatant was collected and applied to the cytokine ELISA kits for measuring the concentrations of TNF- $\alpha$ and IL- $1 \beta$.

\subsection{Western blot analysis}

Approximately 15 micrograms total proteins cellular extracts or $25 \mu \mathrm{L}$ per lane were loaded onto a $12 \%$ SDS-PAGE gel. After electrophoretic separation, proteins were transferred to a polyvinylidene fluoride membrane. The membrane was blocked with 5\% fat-free skim milk in Tris buffered saline with tween-20 buffer at room temperature for $1 \mathrm{~h}$, and then incubated with mouse monoclonal HMGB1 antibody (1:1,000; Abcam, Cambridge, UK) or mouse monoclonal $\beta$-actin antibody $(1: 1,000$; Santa Cruz Technology, Santa Cruz, CA) respectively at $4{ }^{\circ} \mathrm{C}$ overnight. After being washed, the membrane was incubated with goat anti-mouse secondary antibody conjugated with horseradish peroxidase at 1:5000 for $1 \mathrm{~h}$, then followed by an extensive wash. The signal was visualized with enhanced chemiluminescence (GE Healthcare) and quantitated by densitometry through using Quantity One software. The expression level of HMGB1 proteins in total proteins cellular extracts was normalized by $\beta$-actin levels.

\subsection{Reverse transcription-polymerase chain reaction (RT-PCR) analysis}

The detailed procedures of RT-PCR and the primer sequences, which were used in this research were reported in our previous investigations (Liu et al., 2017; Zou et al., 2017). The analysis was conducted three times independently.

\subsection{Determination of nuclear translocation of NF- $\kappa B$}

Macrophages were pretreated with compounds 1 and $2(10,20,30,40$, or $50 \mu \mathrm{M})$ for $1 \mathrm{~h}$ then exposed to LPS $(100 \mathrm{ng} / \mathrm{mL})$ for $2 \mathrm{~h}$, respectively. After the stimulation period, the RAW264.7 cells were harvested and washed 3 times with cold PBS. The cytoplasmic and nuclear extracts were prepared using a nuclear/cytosol fractionation kit (Biovision, Inc., Mountain View, CA, USA) according to manufacturer's instructions. Cytoplasmic and nuclear fractions were measured for levels of NF- $\mathrm{KB}$ using a commercially available NF- $\mathrm{kB}$ p65 ELISA kit (Cell Signaling Technology, Inc.), according to the manufacturer's instructions.

\subsection{Statistical analysis}

All continuous data were expressed as the mean \pm SD. Comparisons between groups were performed by one wayANOVA analysis or Student's t-test. Statistical significance was defined as a $P<0.05$. All statistical analyses were performed by using SPSS 16.0 for Windows.

\section{Results}

\subsection{Cell viability}

To investigate the cytotoxicity of compounds $\mathbf{1}$ and $\mathbf{2}$ on RAW264.7 macrophage cells, the viability of RAW264.7 cells were determined through an MTT-based EZ4U assay. The cytotoxicity of compounds 1 and 2 at different concentrations $(5,25,50,75$, and $100 \mu \mathrm{M})$ are shown in Figure 2. No obvious cytotoxicity was observed up to $50 \mu \mathrm{M}$ but significant cytotoxicity was observed in RAW264.7 cells when being treated with compounds $\mathbf{1}$ and $\mathbf{2}$ at concentrations that higher than $50 \mu \mathrm{M}$, respectively. The subsequent experiments were therefore performed at concentrations that not higher than $50 \mu \mathrm{M}$ for these two isolates.

\subsection{Effects of compounds 1 and 2 on production of TNF- $\alpha$ and IL-1 $\beta$ in LPS-stimulated RAW264.7 macrophages}

LPS-induced RAW264.7 macrophages were used to evaluate the inhibitory action of compounds $\mathbf{1}$ and $\mathbf{2}$ on the production of TNF- $\alpha$ and IL- $1 \beta$. Cells were preincubated with various concentrations $(10,20,30,40$, and $50 \mu \mathrm{M})$ of compounds 1 and 2 respectively prior to LPS $(100 \mathrm{ng} / \mathrm{mL})$ treatment, then the TNF- $\alpha$ and IL- $1 \beta$ levels in the cell culture medium were measured by ELISA assay. As shown in Figure 3A, compounds 1 and 2 inhibited TNF- $\alpha$ production in a concentration-dependent manner $(P<0.05)$. In case of IL-1 $\beta$ production, all these two compounds displayed concentration-dependent inhibitory effects $(P<0.05$, Figure 3B). To confirm whether the inhibition of TNF- $\alpha$ and IL- $1 \beta$ production was due to the decreased gene expression, we examined the mRNA levels of IL- $1 \beta$ and TNF- $\alpha$ in the LPSstimulated RAW 264.7 cells. As presented in Figure 3C and 3D, the pretreatment with compounds $\mathbf{1}$ and $\mathbf{2}$ suppressed the mRNA expression of TNF- $\alpha$ and IL- $1 \beta$, coincident with the TNF- $\alpha$ and IL-1 $\beta$ protein levels in the cell culture medium. These results showed that compounds $\mathbf{1}$ and $\mathbf{2}$ inhibited the expression of IL- $1 \beta$ and TNF- $\alpha$ at the transcriptional level, which, in turn, reduced the production of IL- $1 \beta$ and TNF- $\alpha$ in the LPS-stimulated RAW 264.7 cells. 


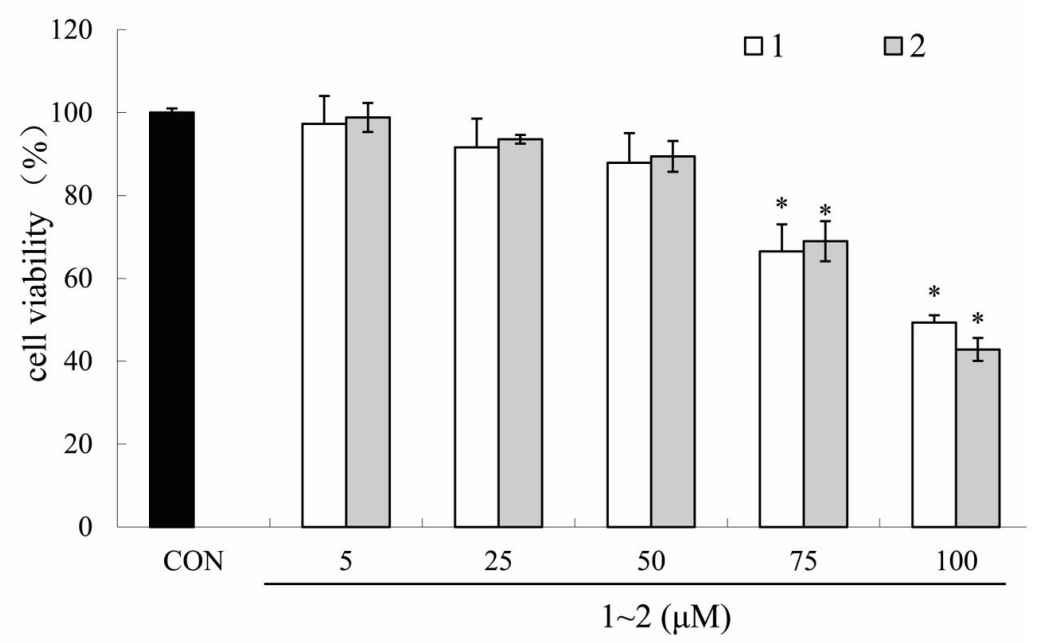

Figure 2. Cell viability in RAW264.7 macrophages treated with lupane-type triterpenes (1 and 2). RAW264.7 cells were exposed to $\mathbf{1}$ and $\mathbf{2}$ at the indicated concentrations for $48 \mathrm{~h}$ and evaluated by MTT-based EZ4U test. Cell viability of treated samples was expressed as a percentage of surviving cells compared with that in the vehicle control. Values are expressed as mean \pm S.D. of three individual experiments performed in triplicate. CON stands for vehicle control. ${ }^{\star} P<0.05$ vs. the control group.

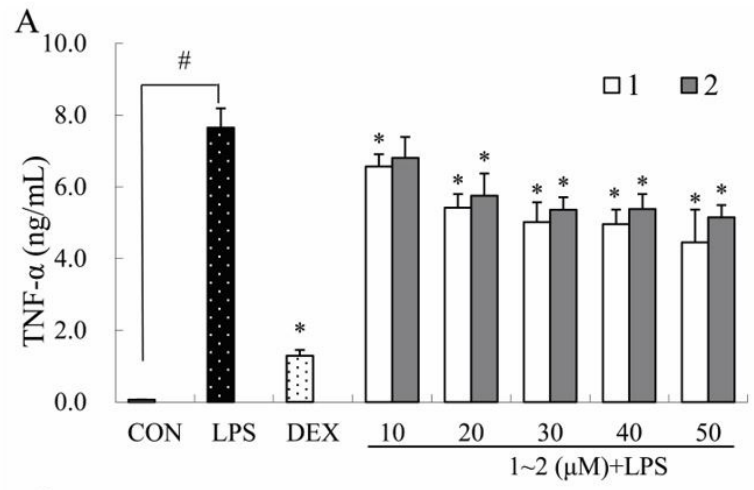

C

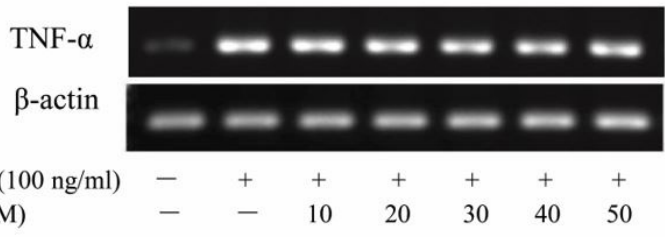

TNF- $\alpha$

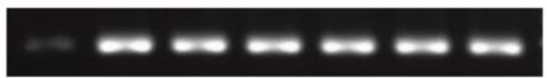

$\beta$-actin

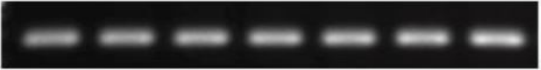

$\operatorname{LPS}(100 \mathrm{ng} / \mathrm{ml})$

$2(\mu \mathrm{M})$
B

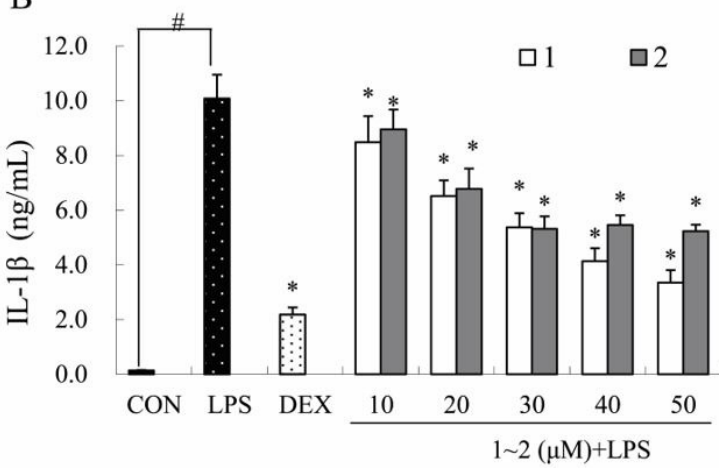

$\mathrm{D}$

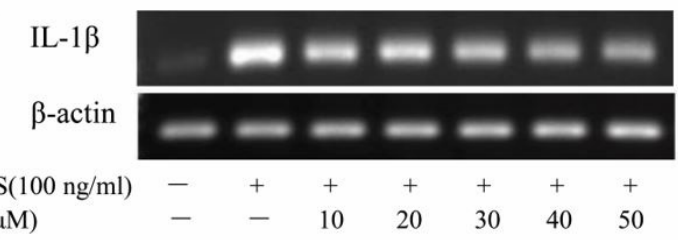

IL-1 $\beta$

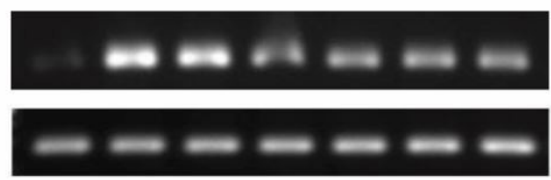

$\mathrm{LPS}(100 \mathrm{ng} / \mathrm{ml}) \quad-\quad+\quad+\quad+\quad+\quad+\quad+$

$\begin{array}{llllllll}2(\mu \mathrm{M}) & - & - & 10 & 20 & 30 & 40 & 50\end{array}$

Figure 3. Effects of lupane-type triterpenes (1 and $\mathbf{2}$ ) on LPS-induced TNF- $\alpha$ and IL-1 $\beta$ production and mRNA expression in RAW264.7 cells. (A, B) Effects of 1 and 2 on LPS-induced TNF- $\alpha$ (A) and IL-1 $\beta$ (B) production. The concentration of TNF- $\alpha$ and IL- $1 \beta$ secreted by RAW264.7 was measured by commercially available sandwich ELISA kits. Control (CON) values were obtained in the absence of LPS and compounds 1 and 2 . LPS values were obtained in the presence of LPS (100 ng/mL) and absence of compounds $\mathbf{1}$ and $\mathbf{2}$. The positive control (DEX) was obtained in the presence of LPS $(100 \mathrm{ng} / \mathrm{mL})$ and Dexamethasone $(10 \mu \mathrm{M})$. Three independent experiments were performed with similar results. Data is expressed as mean \pm S.D. Student's t-test was used to determine significant differences between two groups. $\# P<0.05$ vs. negative controls $(\mathrm{CON}) ;{ }^{*} P<0.05 \mathrm{vs.} 100 \mathrm{ng} / \mathrm{mL}$ LPStreated cells; (C, D) Effects of lupane-type triterpenes (1 and $\mathbf{2})$ on mRNA expression of TNF- $\alpha$ and IL-1 $\beta$ in LPS-stimulated macrophages. RAW 264.7 cells were pre-incubated with various concentrations of lupane-type triterpenes 1 and $\mathbf{2}$ for $1 \mathrm{~h}$ and were then treated with $100 \mathrm{ng} / \mathrm{mL} \mathrm{LPS}$ for an additional $2 \mathrm{~h}$. mRNA expression of TNF- $\alpha(\mathbf{C})$ and IL-1 $\beta$ (D) was analyzed by real-time RT-PCR and $\beta$-actin was used as the internal control. 


\subsection{Effects of compounds 1 and 2 on secretion of HMGB1 in LPS-induced RAW264.7 macrophages}

To examine the effect of compounds $\mathbf{1}$ and $\mathbf{2}$ on the production of HMGB1, the RAW264.7 cells were incubated with compounds 1 and 2 respectively and then exposed to LPS (100 ng/mL). The HMGB1 protein levels from the culture medium of macrophages or whole cell lysate were analyzed by western blot assay. The protein levels were significantly increased in the culture medium of RAW264.7 cells after LPS stimulation as shown in Figure 4A and 4B, compounds 1 and 2 effectively attenuated LPS-induced HMGB1 release $(P<0.05)$, in a dose dependent manner. However, compound $\mathbf{1}$ displayed the better inhibitory effect on the LPS-induced HMGB1 release. No significant change in levels of HMGB1 protein from whole cell lysates was observed at the presence of these triterpene compounds (Figure 4C). Thus, compounds $\mathbf{1}$ and $\mathbf{2}$ attenuated endotoxin-induced HMGB1 secretion from macrophage into extracellular milieu, without changing the HMGB1 protein levels inside the RAW 264.7 cells.

\subsection{Effects of compounds 1 and 2 on transcriptional activity of NF- $\kappa B$ in LPS-stimulated RAW264.7 macrophages}

Activation of macrophages leads to the translocation of NF- $\kappa B$ to nucleus and gene expression. The levels of nuclear NF$\kappa \mathrm{B}$ were measured by ELISA assay to assess the transcriptional activity of NF- $\mathrm{KB}$. As shown in Figure 5, the protein levels of NF- $\kappa B$ (p65) in the nucleus of the LPS-stimulated cells were significantly increased compared with the control group. Lupanetype triterpenes $\mathbf{1}$ and $\mathbf{2}$ significantly reduced the NF- $\mathrm{kB}$ activity in LPS-stimulated RAW264.7 cells in a dose-dependent manner (Figure 5A and 5B).

\section{Discussion}

The inhibition of inflammatory mediators and cytokines is considered as an effective therapeutic strategy for the treatment of inflammatory diseases. 3a,11a-dihydroxy-23-oxo-lup-20(29)en-28-oic acid (1) and 3a,11a,23-trihydroxy-lup-20(29)-en-28oic acid (2) were considered as the active components of AGS. However, the effect and underlying mechanism of $\mathbf{1}$ and $\mathbf{2}$ on inflammatory progress have not been fully assessed. In this study, we demonstrated that compound $\mathbf{1}$ and $\mathbf{2}$ suppressed the expression of inflammatory cytokines including TNF- $\alpha$, IL- $1 \beta$, and HMGB1 mediated through NF- $\kappa B$ signaling pathway in LPS-stimulated RAW264.7 cells in vitro.

Numerous publications have demonstrated the key player of proinflammatory cytokines in the inflammation (Jia et al., 2017). Overexpression of TNF- $\alpha$ and IL- $1 \beta$, as common early inflammatory cytokines, leads to a variety of chronic and acute inflammatory diseases, including rheumatoid arthritis, Crohn's disease, sepsis (Gil et al., 2016; Xiao et al., 2021). In this study, LPS significantly enhanced the expressions of TNF- $\alpha$ and IL- $1 \beta$ in RAW264.7 macrophages. Simultaneously, treatment with 1 and $\mathbf{2}$ markedly decreased the expressions of TNF- $\alpha$ and IL-1 $\beta$, suggesting that the anti-inflammatory effects of $\mathbf{1}$ and 2 were related to the inhibition of early inflammatory cytokine expressions.
A

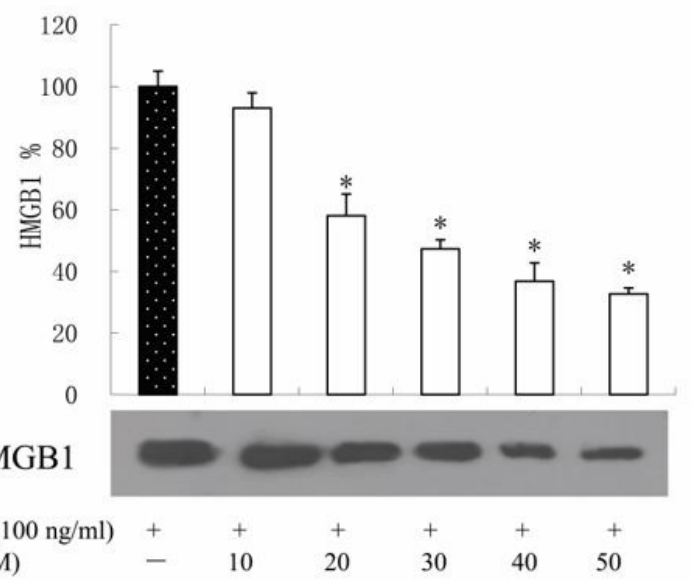

B

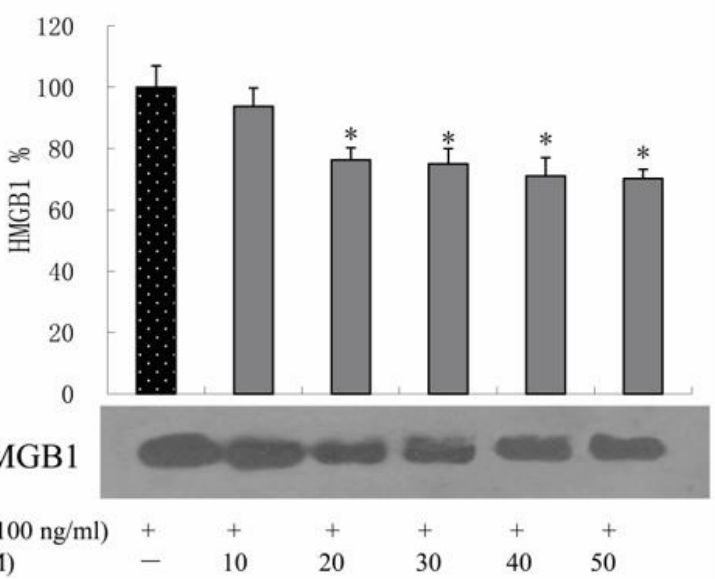

$\mathrm{C}$

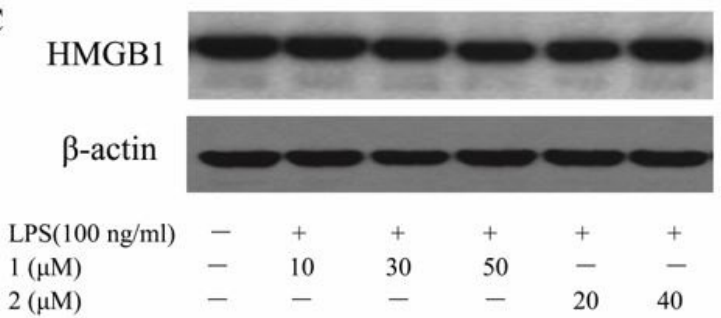

Figure 4. Effects of lupane-type triterpenes ( 1 and 2 ) on the expression of HMGB1 protein in LPS-induced RAW264.7 cells. (A) Effect of different concentrations of compound $\mathbf{1}$ on the expression of HMGB1 protein in the supernatant and quantitative densitometric analysis of HMGB1 protein in LPS-treated RAW264.7 cells. (B) Effect of different concentrations of compound $\mathbf{2}$ on the expression of HMGB1 protein in the supernatant and quantitative densitometric analysis of HMGB1 protein in LPS-treated RAW264.7 cells. Mean values \pm SD $(n=3) .{ }^{*} P$ $<0.05$ compared with the LPS-treatment group; (C) Effects of 1 and 2 on the expression of HMGB1 protein in intracellular of LPS-induced RAW264.7 cells. The expression level of HMGB1 protein in cellular extracts was normalized by $\beta$-actin levels.

HMGB1 is a DNA binding protein that maintains nucleosomal structures and regulates gene transcription, which is characterized by highly conserved proteins (Fu \& Nishibori, 2019; Yun et al., 2021). Recent studies have suggested that it exhibits a pronounced proinflammatory effect in the inflammatory response, which is involved in the process of development of 
A

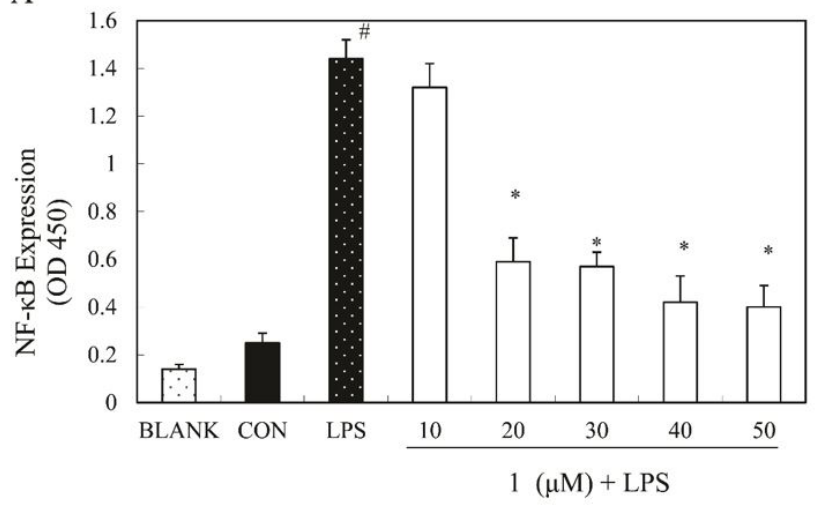

B

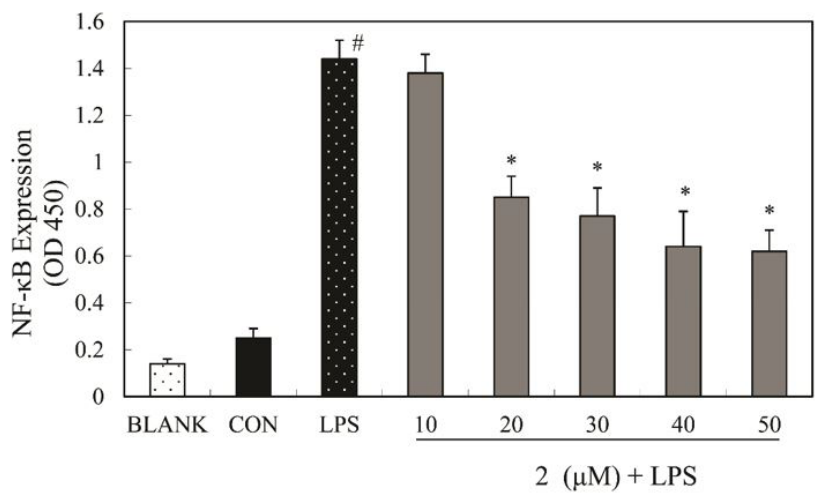

Figure 5. Effects of lupane-type triterpenes (1 and 2) on NF- $\kappa B$ transcriptional activity in LPS-induced RAW264.7 cells. Lupane-type triterpenes $\mathbf{1}(\mathrm{A})$ and $\mathbf{2}(\mathrm{B})$ reduces NF- $\kappa \mathrm{B}$ activity in a dose-dependent manner. RAW264.7 cells were stimulated with or without LPS (100 $\mathrm{ng} / \mathrm{mL}$ ) in the absence or presence of lupane-type triterpenes ( 1 and 2) $(10,20,30,40$ or $50 \mu \mathrm{M})$ for $2 \mathrm{~h}$. Nuclear proteins were extracted, and NF- $\kappa \mathrm{B}$ activity was determined by NF- $\kappa \mathrm{B}$ p 65 ELISA kit (Cell Signaling Technology, Inc). Control (CON) values were obtained in the absence of LPS and lupane-type triterpenes (1 and $\mathbf{2})$. LPS values were obtained in the presence of LPS $(100 \mathrm{ng} / \mathrm{mL})$ and absence of lupane-type triterpenes ( $\mathbf{1}$ and $\mathbf{2})$. Mean values $\pm \mathrm{SD}(\mathrm{n}=3)$. $\# P<0.05$ compared with the control group. ${ }^{\star} P<0.05$ compared with the LPStreatment group.

sepsis (Okamoto et al., 2016; Zhou et al., 2018; Ni et al., 2020), as well as the important inflammatory mediators for the late period (Kang et al., 2014; Wang et al., 2014). Previous studies about the pathogenesis of inflammatory diseases like sepsis have only highlighted the early inflammatory mediators in the course of sepsis (Tracey et al., 1987; Tracey \& Lowry, 1990). However, clinical trials of drugs with inhibitory effects on early cytokines such as TNF- $\alpha$ and IL-1 $\beta$ failed to improve survival in septic patients (Abraham et al., 1995; Sundén-Cullberg et al., 2005). Unlike the early release and disappearance of TNF- $\alpha$ and IL-1 $\beta$, the serum concentrations of HMGB1 increase within 8 to 32 hours and maintain high levels for at least 96 hours (Wang et al., 2011). Moreover, HMGB1 appears to activate macrophages leading to the secretion of multiple cytokines, which in turn cause extensive inflammatory responses, including TNF- $\alpha$ and IL-1 $\beta$ (Luan et al.,
2013; Guzmán-Ruiz et al., 2014; Liu et al., 2017). Based on these findings, HMGB1 may be considered as a potent therapeutic target in inflammatory diseases like sepsis in clinical practice (Wang et al., 2015). Our results also show that compounds 1 and 2 significantly reversed elevated HMGB1 protein levels after LPS stimulation in the RAW264.7 cell supernatant. Since these compounds didn't change the protein levels of HMGB1, so the downregulation caused by them may through the inhibition of HMGB1 secretion. As a result, triterpenes 1 or 2 may be promising agent for reducing HMGB1-inducing inflammation.

A large number of evidences suggest that NF- $\mathrm{KB}$ is a key transcription factor for the production of inflammatory cytokine in a variety of diseases. In this study, we found that LPS led to a significant elevation of nuclear level of NF- $\kappa B$ in RAW264.7 cells, which indicated that LPS induced the nuclear translocation of NF- $\mathrm{KB}$. At the same time, treatment of isolates $\mathbf{1}$ and $\mathbf{2}$ significantly decreased the nuclear level of NF- $\mathrm{kB}$. These research results, along with our findings in this work, indicate that $\mathbf{1}$ and $\mathbf{2}$ inhibits NF- $\mathrm{KB}$ activation via targeting various signaling molecules in diverse factor-induced inflammatory conditions. In the further study, the detailed description for natural products $\mathbf{1}$ and $\mathbf{2}$ on LPS-induced NF- $\mathrm{KB}$ activation in macrophages and the potential signal transduction pathways should be done.

\section{Conclusion}

Altogether, the present study shown that two lupane-type triterpenoids, 3a,11a-dihydroxy-23-oxo- lup-20(29)-en-28-oic acid (1) and 3a,11a,23-trihydroxy-lup-20(29)-en-28-oic acid (2), relieved the inflammatory response induced not only by early pro-inflammatory mediators such as TNF- $\alpha$, IL- $1 \beta$, and NF- $\kappa B$ but also by late proinflammatory cytokine HMGB1. These results warrant that the further studies would concerning the candidate therapy for inflammatory diseases like sepsis of lupane-type triterpenoids containing in the leaves of AGS. In addition, the leaves of AGS contains abundant lupane-type triterpenoids and saponins, which were also found to have significant anti-inflammatory activity in our previous reports (Liu et al., 2002, 2004, 2017; Yook et al., 2002; Zou et al., 2011, 2017). This research provides a reliable theoretical and practical basis for application of the leaves of AGS as function food and the development of drugs for inflammatory-related diseases in the future.

\section{Conflict of interest}

The authors declare that there are no conflicts of interest regarding the publication of this article.

\section{Availability of data and material}

The data used to support the findings of this study are available from the corresponding author upon request.

\section{Funding}

This work was supported by a grant from the Natural Science Foundation of Hunan Province, China (2019JJ40223); and the 
Doctoral Scientific Research Starting Foundation of Gannan Medical University (QD201905).

\section{Author contributions}

Jiao LUO and Xiao-Jun LI contributed equally to this work.

\section{References}

Abraham, E., Wunderink, R., Silverman, H., Perl, T. M., Nasraway, S., Levy, H., Bone, R., Wenzel, R. P., Balk, R., Allred, R. (1995). Efficacy and safety of monoclonal antibody to human tumor necrosis factor alpha in patients with sepsis syndrome: a randomized, controlled, double-blind, multicenter clinical trial. TNF-alpha MAb sepsis study group. Journal of the American Medical Association, 273(12), 934-941. http://dx.doi.org/10.1001/jama.1995.03520360048038. PMid:7884952.

Ahn, S., Singh, P., Jang, M., Kim, Y.-J., Castro-Aceituno, V., Simu, S. Y., Kim, Y. J., \& Yang, D.-C. (2018). Gold nanoflowers synthesized using Acanthopanacis cortex extract inhibit inflammatory mediators in LPS-induced RAW264.7 macrophages via NF- $\kappa$ B and AP-1 pathways. Colloids and Surfaces B, Biointerfaces, 162, 398-404. http://dx.doi. org/10.1016/j.colsurfb.2017.11.037. PMid:29245117.

Cao, L., Li, Z., Yang, Z., Wang, M., Zhang, W., Ren, Y., Li, L., Hu, J., Sun, Z., \& Nie, S. (2021). Ferulic acid positively modulates the inflammatory response to septic liver injury through the GSK-3 $\beta$ / NF-кB/CREB pathway. Life Sciences, 277, 119584. http://dx.doi. org/10.1016/j.lfs.2021.119584. PMid:33961853.

Chinese Pharmacopoeia Commission. (2015). Pharmacopoeia of the People's Republic of China. Beijing: China Medical Science Press.

Fu, L., \& Nishibori, M. (2019). The role of high mobility group box-1 in epileptogenesis. Acta Medica Okayama, 73(5), 383-386. PMid:31649363.

Gil, M., Kim, Y. K., Hong, S. B., \& Lee, K. J. (2016). Naringin decreases TNF- $\alpha$ and HMGB1 release from LPS-Stimulated macrophages and improves survival in a CLP-induced sepsis mice. PLoS One, 11(10), e0164186. http://dx.doi.org/10.1371/journal.pone.0164186. PMid:27716835.

Guzmán-Ruiz, R., Ortega, F., Rodríguez, A., Vázquez-Martínez, R., Díaz-Ruiz, A., Garcia-Navarro, S., Giralt, M., Garcia-Rios, A., Cobo-Padilla, D., Tinahones, F., López-Miranda, J., Villarroya, F., Frühbeck, G., Fernández-Real, J., \& Malagón, M. (2014). Alarmin high-mobility group B1 (HMGB1) is regulated in human adipocytes in insulin resistance and influences insulin secretion in $\beta$-cells. International Journal of Obesity, 38(12), 1545-1554. http://dx.doi. org/10.1038/ijo.2014.36. PMid:24577317.

Han, Y., Zhang, X., Kang, Y., Gao, Y., Li, X., Qi, R., Cai, R., \& Qi, Y. (2021). Sophoraflavanone M, a prenylated flavonoid from Sophora flavescens Ait., suppresses pro-inflammatory mediators through both NF- $\kappa \mathrm{B}$ and JNK/AP-1 signaling pathways in LPS-primed macrophages. European Journal of Pharmacology, 907, 174246. http://dx.doi.org/10.1016/j.ejphar.2021.174246. PMid:34118222.

Hsieh, W.-T., Hsu, M.-H., Lin, W.-J., Xiao, Y.-C., Lyu, P.-C., Liu, Y.-C., Lin, W.-Y., Kuo, Y.-H., \& Chung, J.-G. (2021). Ergosta-7, 9 (11), 22 -trien-3 $\beta$-ol interferes with LPS docking to LBP, CD14, and TLR4/MD-2 co-receptors to attenuate the NF- $\kappa \mathrm{B}$ inflammatory pathway in vitro and drosophila. International Journal of Molecular Sciences, 22(12), 6511. http://dx.doi.org/10.3390/ijms22126511. PMid:34204506.

Hur, J., Lee, H. G., Kim, E., Won, J. P., Cho, Y., Choi, M.-J., Lee, H., \& Seo, H. G. (2021). Ginseng leaf extract ameliorates the survival of endotoxemic mice by inhibiting the release of high mobility group box 1. Journal of Food Biochemistry, 45(7), e13805. http://dx.doi. org/10.1111/jfbc.13805. PMid:34096077.

Hwangbo, H., Ji, S. Y., Kim, M. Y., Kim, S. Y., Lee, H., Kim, G.-Y., Kim, S., Cheong, J., \& Choi, Y. H. (2021). Anti-inflammatory effect of auranofin on palmitic acid and LPS-Induced inflammatory response by modulating TLR4 and NOX4-mediated NF- $\kappa B$ signaling pathway in RAW264.7 macrophages. International Journal of Molecular Sciences, 22(11), 5920. http://dx.doi.org/10.3390/ijms22115920. PMid:34072916.

Insuan, O., Janchai, P., Thongchuai, B., Chaiwongsa, R., Khamchun, S., Saoin, S., Insuan, W., Pothacharoen, P., Apiwatanapiwat, W., Boondaeng, A., \& Vaithanomsat, P. (2021). Anti-inflammatory effect of pineapple rhizome bromelain through downregulation of the NF-B- and MAPKs-signaling pathways in lipopolysaccharide (LPS)-stimulated RAW264.7 cells. Current Issues in Molecular Biology, 43(1), 93-106. http://dx.doi.org/10.3390/cimb43010008. PMid:34067064.

Jia, J., Sun, Y., Hu, Z., Li, Y., \& Ruan, X. (2017). Propofol inhibits the release of interleukin-6, 8 and tumor necrosis factor- $\alpha$ correlating with high-mobility group box1 expression in lipopolysaccharidesstimulated RAW 264.7 cells. BMC Anesthesiology, 17(1), 148. http:// dx.doi.org/10.1186/s12871-017-0441-0. PMid:29073894.

Kang, R., Chen, R., Zhang, Q., Hou, W., Wu, S., Cao, L., Huang, J., Yu, Y., Fan, X., Yan, Z., Sun, X., Wang, H., Wang, Q., Tsung, A., Billiar, T. R., Zeh, H. J. 3rd, Lotze, M. T., \& Tang, D. (2014). HMGB1 in health and disease. Molecular Aspects of Medicine, 40, 113. http:// dx.doi.org/10.1016/j.mam.2014.05.001. PMid:25010388.

Lin, X., Zhang, J., Fan, D., Hou, J., Wang, H., Zhu, L., Tian, R., An, X., \& Yan, M. (2021). Frutescone O from Baeckea frutescens blocked TLR4-mediated myd88/NF- $\kappa \mathrm{B}$ and MAPK signaling pathways in LPS induced RAW264.7 macrophages. Frontiers in Pharmacology, 12, 643188. http://dx.doi.org/10.3389/fphar.2021.643188. PMid:33986676.

Liu, X.-Q., Chang, S.-Y., Park, S.-Y., Nohara, T., \& Yook, C.-S. (2002). A new lupane-triterpene glycoside from the leaves of Acanthopanax gracilistylus. Archives of Pharmacal Research, 25(6), 831-836. http:// dx.doi.org/10.1007/BF02977000. PMid:12510834.

Liu, X.-Q., Yook, C.-S., \& Chang, S.-Y. (2004). Chemical constituents of Acanthopanax gracilistylus. Chinese Traditional and Herbal Drugs, 35(3), 250-252.

Liu, X.-Q., Zou, Q.-P., Huang, J.-J., Yook, C.-S., Whang, W.-K., Lee, H.-K., \& Kwon, O.-K. (2017). Inhibitory effects of 3a-hydroxy-lup20(29)-en-23, 28-dioic acid on lipopolysaccharide-induced TNF- $\alpha$, IL- $1 \beta$, and the high mobility group box 1 release in macrophages. Bioscience, Biotechnology, and Biochemistry, 81(7), 1305-1313. http://dx.doi.org/10.1080/09168451.2017.1301803. PMid:28345393.

Lu, M.-X., Yang, Y., Zou, Q.-P., Luo, J., Zhang, B.-B., Liu, X.-Q., \& Hwang, E.-H. (2018). Anti-diabetic effects of Acankoreagenin from the leaves of Acanthopanax Gracilistylus herb in RIN-m5F cells via suppression of NF- $\kappa B$ activation. Molecules, 23(4), 958. http://dx.doi. org/10.3390/molecules23040958. PMid:29671829.

Luan, Z.-G., Zhang, J., Yin, X.-H., Ma, X.-C., \& Guo, R.-X. (2013). Ethyl pyruvate significantly inhibits tumour necrosis factor- $\alpha$, interleukin- $1 \beta$ and high mobility group box 1 releasing and attenuates sodium taurocholate-induced severe acute pancreatitis associated with acute lung injury. Clinical and Experimental Immunology, 172(3), 417-426. http://dx.doi.org/10.1111/cei.12062. PMid:23600830.

Luo, Q.-J., Sun, M.-X., Guo, Y.-W., Tan, S.-W., Wu, X.-Y., Abassa, K.-K., Lin, L., Liu, H.-L., Jiang, J., \& Wei, X.-Q. (2020). Sodium butyrate protects against lipopolysaccharide-induced liver injury partially via the GPR43/ $\beta$-arrestin-2/NF- $\mathrm{B}$ network. Gastroenterology 
Report, 9(2), 154-165. http://dx.doi.org/10.1093/gastro/goaa085. PMid:34026223.

Ni, J., Zhao, Y., Su, J., Liu, Z., Fang, S., Li, L., Deng, J., \& Fan, G. (2020). Toddalolactone protects lipopolysaccharide-induced sepsis and attenuates lipopolysaccharide-induced inflammatory response by modulating HMGB1-NF- $\mathrm{kB}$ translocation. Frontiers in Pharmacology, 11, 109. http://dx.doi.org/10.3389/fphar.2020.00109. PMid:32153412.

Okamoto, K., Tamura, T., \& Sawatsubashi, Y. (2016). Sepsis and disseminated intravascular coagulation. Journal of Intensive Care, 4(1), 23. http://dx.doi.org/10.1186/s40560-016-0149-0. PMid:27011792.

Shan, B. E., Yoshita, Y., Sugiura, T., \& Yamashita, U. (1999). Suppressive effect of Chinese medicinal herb, Acanthopanax gracilistylus, extract on human lymphocytes in vitro. Clinical and Experimental Immunology, 118(1), 41-48. http://dx.doi.org/10.1046/j.1365-2249.1999.01031.x. PMid:10540158.

State Administration of Traditional Chinese Medicine. (1999). Chinese Materia medica. Shanghai: Shanghai Scientific \& Technical Publishers.

Sundén-Cullberg, J., Norrby-Teglund, A., Rouhiainen, A., Rauvala, H., Herman, G., Tracey, K. J., Lee, M. L., Andersson, J., Tokics, L., \& Treutiger, C. J. (2005). Persistent elevation of high mobility group box-1 protein (HMGB1) in patients with severe sepsis and septic shock. Critical Care Medicine, 33(3), 564-573. http://dx.doi. org/10.1097/01.CCM.0000155991.88802.4D. PMid:15753748.

Tang, P., Li, Q., Liao, S., Wei, S., Cui, L., Xu, W., Zhu, D., Luo, J., \& Kong, L. (2021). Shizukaol a exerts anti-Inflammatory effect by regulating HMGB1/Nrf2/HO-1 pathway. Phytomedicine, 82, 153472. http:// dx.doi.org/10.1016/j.phymed.2021.153472. PMid:33550145.

Tracey, K. J., \& Lowry, S. F. (1990). The role of cytokine mediators in septic shock. Advances in Surgery, 23(23), 21-56. PMid:2403458.

Tracey, K. J., Fong, Y., Hesse, D. G., Manogue, K. R., Lee, A. T., Kuo, G. C., Lowry, S. F., \& Cerami, A. (1987). Anti-cachectin/TNF monoclonal antibodies prevent septic shock during lethal bacteraemia. Nature, 330(6149), 662-664. http://dx.doi.org/10.1038/330662a0. PMid:3317066.

Wang, H., Ward, M. F., \& Sama, A. E. (2014). Targeting HMGB1 in the treatment of sepsis. Expert Opinion on Therapeutic Targets, 18(3), 257-268. http://dx.doi.org/10.1517/14728222.2014.863876 . PMid:24392842.

Wang, H.-L., Zhang, W.-H., Lei, W.-F., Zhou, C.-Q., \& Ye, T. (2011). The inhibitory effect of lidocaine on the release of high mobility group box 1 in lipopolysaccharide-stimulated macrophages. Anesthesia and Analgesia, 112(4), 839-844. http://dx.doi.org/10.1213/ ANE.0b013e31820dca9f. PMid:21288974.

Wang, Q., Yokoo, H., Takashina, M., Sakata, K., Ohashi, W., Abedelzaher, L. A., Imaizumi, T., Sakamoto, T., Hattori, K., Matsuda, N., \& Hattori, Y. (2015). Anti-inflammatory profile of levosimendan in cecal ligation-induced septic mice and in lipopolysaccharide-stimulated macrophages. Critical Care Medicine, 43(11), e508-e520. http:// dx.doi.org/10.1097/CCM.0000000000001269. PMid:26468714.

Wang, Y., Zhang, H., Chen, Q., Jiao, F., Shi, C., Pei, M., Lv, J., Zhang, H., Wang, L., \& Gong, Z. (2020). TNF-a/HMGB1 inflammation signalling pathway regulates pyroptosis during liver failure and acute kidney injury. Cell Proliferation, 53(6), e12829. http://dx.doi. org/10.1111/cpr.12829. PMid:32419317.
Wei, F., Zhu, H., Li, N., Yu, C., Song, Z., Wang, S., Sun, Y., Zheng, L., Wang, G., Huang, Y., Bao, Y., \& Sun, L. (2021). Stevioside activates AMPK to suppress inflammation in macrophages and protects mice from LPS-induced lethal shock. Molecules, 26(4), 858. http://dx.doi. org/10.3390/molecules26040858. PMid:33562046.

Xiao, J., Thwe, A. A., Liu, T., Gong, D., Lin, W., Shang, C., \& Lu, Z. (2021). Anti-inflammatory effects of an extract from Pseudomonas aeruginosa and its purified product 1-hydroxyphenazine on RAW264.7 cells. Current Microbiology, 78(7), 2762-2773. http://dx.doi.org/10.1007/ s00284-021-02544-3. PMid:34043026.

Xu, J.-J., Gong, L.-L., Li, Y.-Y., Zhou, Z.-B., Yang, W.-W., Wan, C.-X., \& Zhang, W.-N. (2021a). Anti-inflammatory effect of a polysaccharide fraction from Craterellus cornucopioides in LPS-stimulated macrophages. Journal of Food Biochemistry, 45(8), e13842. http:// dx.doi.org/10.1111/jfbc.13842. PMid:34189750.

Xu, Q., Qiao, Y., Zhang, Z., Deng, Y., Chen, T., Tao, L., Xu, Q., Liu, J., Sun, W., Ye, Y., Lu, Y., Qi, C., \& Zhang, Y. (2021b). New polyketides with anti-Inflammatory activity from the Fungus Aspergillus rugulosa. Frontiers in Pharmacology, 12, 700573. http://dx.doi.org/10.3389/ fphar.2021.700573. PMid:34234683.

Yang, H., Lundbäck, P., Ottosson, L., Erlandsson-Harris, H., Venereau, E., Bianchi, M. E., Al-Abed, Y., Andersson, U., \& Tracey, K. J. (2021). Redox modification of Cysteine Residues regulates the cytokine activity of high mobility group box-1 (HMGB1). Molecular Medicin, 27(1), 58. http://dx.doi.org/10.1186/s10020-021-00307-1. PMid:34098868.

Yook, C. S., Liu, X. Q., Chang, S. Y., Park, S. Y., \& Nohara, T. (2002). Lupane-triterpene glycosides from the leaves of Acanthopanax gracilistylus. Chemical \& Pharmaceutical Bulletin, 50(10), 1383-1385. http://dx.doi.org/10.1248/cpb.50.1383. PMid:12372869.

Yun, B. H., Kim, S., Chon, S. J., Kim, G. H., Choi, Y. S., Cho, S., Lee, B. S., \& Seo, S. K. (2021). High mobility group box-1 promotes inflammation in endometriotic stromal cells through Toll-like receptor 4/nuclear factor-kappa B. American Journal of Translational Research, 13(3), 1400-1410. PMid:33841665.

Zhang, B.-X., Li, N., Zhang, Z.-P., Liu, H.-B., Zhou, R.-R., Zhong, B.-Y., Zou, M. X., Dai, X. H., Xiao, M. F., Liu, X. Q., \& Fan, X. G. (2011). Protective effect of Acanthopanax gracilistylus-extracted Acankoreanogenin A on mice with fulminant hepatitis. International Immunopharmacology, 11(8), 1018-1023. http://dx.doi.org/10.1016/j. intimp.2011.02.019. PMid:21356341.

Zhou, H., Deng, M., Liu, Y., Yang, C., Hoffman, R., Zhou, J., Loughran, P. A., Scott, M. J., Neal, M. D., \& Billiar, T. R. (2018). Platelet HMGB1 is required for efficient bacterial clearance in intra-abdominal bacterial sepsis in mice. Blood Advances, 2(6), 638-648. http:// dx.doi.org/10.1182/bloodadvances.2017011817. PMid:29563120.

Zou, Q.-P., Liu, X.-Q., \& Lee, H.-K. (2011). Lupane-triterpenoids from the methanol extracts of leaves of Acanthopanax gracilistylus W.W. Smith. Journal of Lanzhou University, 47(6), 120-126.

Zou, Q.-P., Liu, X.-Q., Huang, J.-J., Yook, C.-S., Whang, W.-K., Lee, H.-K., \& Kwon, O.-K. (2017). Inhibitory effects of lupane-type triterpenoid saponins from the leaves of Acanthopanax gracilistylus on lipopolysaccharide-induced TNF- $\alpha$, IL- $1 \beta$ and high-mobility group box 1 release in macrophages. Molecular Medicine Reports, 16(6), 9149-9156. http://dx.doi.org/10.3892/mmr.2017.7767. PMid:29039503. 